\title{
The origin and expansion of regional value chains: the case of Kenyan horticulture
}

DOI:

10.1111/glob.12162

\section{Document Version}

Accepted author manuscript

Link to publication record in Manchester Research Explorer

\section{Citation for published version (APA):}

Krishnan, A. (2018). The origin and expansion of regional value chains: the case of Kenyan horticulture. Global Networks, 18(2), 238-263. https://doi.org/10.1111/glob.12162

\section{Published in:}

Global Networks

\section{Citing this paper}

Please note that where the full-text provided on Manchester Research Explorer is the Author Accepted Manuscript or Proof version this may differ from the final Published version. If citing, it is advised that you check and use the publisher's definitive version.

\section{General rights}

Copyright and moral rights for the publications made accessible in the Research Explorer are retained by the authors and/or other copyright owners and it is a condition of accessing publications that users recognise and abide by the legal requirements associated with these rights.

\section{Takedown policy}

If you believe that this document breaches copyright please refer to the University of Manchester's Takedown Procedures [http://man.ac.uk/04Y6Bo] or contact uml.scholarlycommunications@manchester.ac.uk providing relevant details, so we can investigate your claim.

\section{OPEN ACCESS}


Date of acceptance (prior to copy editing): $8^{\text {th }}$ August 2016

Author:

Aarti Krishnan

Doctoral Researcher, Global Development Institute,

University of Manchester,

Oxford Road, Manchester M13 9PL, UK

aarti.krishnan-2@manchester.ac.uk

\section{The origin and expansion of regional value chains: the case of Kenyan horticulture}

\section{Introduction}

Global value chain (GVC) and global production network (GPN) analysis has provided valuable insights into the role of lead firms from the global North in coordinating their supply chains from upstream retail to the initial stages of production in the global South (e.g. Gereffi 1994; Dicken et al. 2001). Retailers, in particular, have been identified as possessing significant power in coordinating decentralized production in buyer-driven chains (Gereffi 1994, 1999). Extensive research has explored the implications of northern retailers' sourcing strategies for southern suppliers such as farmers, exporters and intermediaries (e.g. Dolan and Humphrey 2000; Henson and Humphrey 2010). Yet, the rapid growth of regional and south-south trade between developing countries over the last two decades has been relatively underexplored by value chain or related production network analysis (Horner 2015). In this context, regional value chains (RVCs) have emerged, involving regional lead firms ${ }^{1}$ that trade within a single world region, such as a country or continent (Barrientos et al. 2016a) as opposed to trading globally (across world regions) in GVCs.

As RVCs expand, how do RVC actors interact and co-exist with GVCs? This question has been insufficiently examined to date, yet is a significant one given actors involved in the expansion of RVCs in southern markets may also participate in GVCs serving northern markets. These markets may differ considerably in terms of standards and procurement strategies of lead buyers, with implications for supplier participation in these chains. Yet it is unclear how actors in RVCs negotiate these distinct requirements of different value chains. While the literature on diffusion of modern retail in the global South (e.g. Neven and Reardon 2006; Reardon et al. 2007) can provide some helpful

\footnotetext{
${ }^{1}$ Regional firms in RVCs may be from the Global South or North, as long as they operate within one world region. This study considers Southern regional lead firms that include organized retail (supermarkets, discounters) and large wholesalers in wet (traditional) markets.
} 
insights, much of that research has focused on consumers and lead buyers (i.e. supermarkets) as key actors, and insufficiently interrogated the evolution and motivation of the different ways in which suppliers participate in RVCs in relation to their interaction with GVCs. The article aims to provide insights not only into how RVCs propagated and co-exist with GVCs, deepening the understanding of their expansion, but to also shed light on the implications of new governance structures and outcomes (bargaining positions, rents) for suppliers from participation in RVCs.

Through a case study of fresh fruit and vegetables (FFV) value chains of French beans and avocados in Kenya, this paper explores expanding retail RVCs where lead-firms ${ }^{2}$ (buyers), producers, intermediaries and consumers all operate within East Africa, particularly Kenya (thus also including domestic markets). FFVs are increasingly sold through coordinated formal channels such as regional supermarkets (Neven and Reardon 2004; Evers et al. 2014). Two types of RVC interactions with GVCs are identified - an 'opportunistic spillover' that creates an 'opportunistic RVC' which is linked closely to GVCs and, second, a more independent, 'targeted' interaction that moves beyond GVC spillover to form targeted RVCs. The first emerges when rejected produce, and as by-product knowledge of good agricultural practices (GAPs) from the GVC and spills over into regional markets, while the second involves supply dedicated to regional markets and meeting standards required by regional supermarkets.

This study draws on mixed method research in Kenya. After mapping the value chain, 39 stakeholders (e.g. exporters, supermarkets, brokers, wholesalers, farmer groups, government officers, business associations and farmers) were interviewed in November 2014 and March 2015. This research also draws on a survey conducted in February and March 2015 for a larger research project on upgrading across different end markets. I performed multistage sampling of 302 farmers growing avocados and French beans. The first stage involved selecting two main regions of production from the Horticultural Crops Directorate validated Crop Statistics Reports 2013 (Meru and Murang'a) and then selecting sub-counties that had the highest proportion of farmers supplying to GVCs and RVCs. In the third stage I randomly sampled farmers from Murang'a (55\% of total sample: 166 farmers) and Meru (45\% of total sample: 136 farmers) counties. Qualitative data was coded using NVivo and quantitative data analysed (cross tabulations, averages and percentages) using Stata statistical software. I used documentary analysis as a means for preparing, validating and triangulating the qualitative and quantitative data.

The next section introduces conceptualizations of RVCs, followed by an overview of the Kenyan case. Subsequently, two types of RVC-GVC interactions are unpacked and their implications discussed, before broader research conclusions are drawn.

\footnotetext{
${ }^{2}$ In this research, unless otherwise specified, buyers are regional lead firms i.e. regional supermarkets. Other regional buyers include: street vendors, kiosks, and wholesalers.
} 


\section{Global to regional value chains}

With growing South-South and intra-regional trade, the dynamics of the development of RVCs are increasingly attracting attention (e.g. Barrientos et al. 2016b). The growth of southern (and regional) end markets can involve a relative shift in the governance regime, as new regional lead firms emerge and have different standards requirements (Evers et al 2014; Pickles et al 2016). Consequentially, growing Southern markets can provide suppliers with new markets, and even upgrading and diversification opportunities, including the possibility to simultaneously serve regional buyers in RVCs along with northern buyers in GVCs (Navas-Aleman 2011). Emerging research on RVCs has sought to unpack their characteristics and development outcomes. These characteristics include the governance processes (e.g. private standards and inclusivity) (Ouma 2010; Barrientos et al. 2016a), as well as the development outcomes of RVCs, such as possibilities for upgrading, poverty reduction and livelihood sustainability (e.g. Minten et al. 2009; Rao and Qaim 2011). Yet, to date, RVC analysis has paid insufficient attention to the interactions and co-existence of RVCs with GVCs.

A parallel strand of literature to that on value chains has studied the emergence of supermarkets in developing countries. Key facilitating conditions which have been identified include the provision of infrastructure (e.g. road networks and communication systems such as mobile phones and social media), the role of the state (e.g. liberalisation policies such as foreign direct investment) (Tschirley et al. 2004) and expanding consumer demand due to growing urbanisation and middle income groups (e.g: Guarin and Knorringa 2014; Hughes et al. 2015). Yet, arguing that consumerdriven explanations are necessary, but not sufficient, conditions for understanding the "waves of diffusion" of organised retail across developing countries from the early 1990s, Reardon et al. (2007) have highlighted the crucial role of lead firm (supermarket) supply strategies. First, regional lead firms introduced cost-efficient, modernized sourcing practices, sometimes through 'learning by imitation' of best practices (such as effective coordination and logistics management) from international retailers. Second, marketing systems were improved through private standards, stable contracts and preferred suppliers, enabling timely procurement of produce. Finally, regional lead firms have been found to have established different store formats to cater to spatially dispersed low, middle, and upper income groups (Neven and Reardon 2006).

While research on both value chains and on the diffusion of modern retail has provided useful insights into the expansion of RVCs, they have insufficiently studied the role of the full range of actors in RVCs, notably suppliers which include producers (farmers, primary marketing organizations), intermediaries and local exporters; regional buyers (supermarkets, wet market actors) and consumers, and the interactions between these actors, particularly in the context of co-existence with GVCs. By considering the interactions (relationships and overlaps) between supplying regional and global markets, this paper provides evidence that identifies how the expansion of RVCs is intrinsically linked to GVCs, with implications for agricultural and social policy. 


\section{Spillovers, strategic diversification and the interaction of RVCs with GVCs}

To help explain the supplier-buyer-consumer interactions in RVCs and the links with GVCs, I draw on the concepts of spillover effects and strategic diversification in value chains. In the context of value chains, spillover effects are understood as by-products of GVC participation. Suppliers may get improved access to inputs, credit, technology transfers and training in GAP to meet international standards. Spillover effects may occur through learning mechanisms of imitation (Pietrobelli and Rabellotti 2011) or via knowledge leakages due to spatial proximity to the global lead firm (Bergman and Feser 2001). Spillovers can also be viewed in terms of product spillovers, when GVC products become popular in local markets and are increasingly sold there (Schimpmann and Qaim 2010).

While previous research has explored the outcomes of different spillovers for participants and non-participants in GVCs, the spillover concept can also be applied to unpack the interactions of RVC actors with GVCs. In this article, spillover effects are decomposed into two types - product and knowledge, which will be elaborated in subsequent sections. Through spillover effects, GVC suppliers may be able to strategically diversify into RVCs. Strategic diversification is a process whereby GVC suppliers spread their risk by simultaneously participating in multiple value chains with different governance regimes (different lead buyers) (Navas-Aleman 2011; Barrientos et al. 2016a). Thus, for example, suppliers from the global South may thus serve Northern buyers in GVCs and Southern buyers in RVCs at the same time.

This paper will scrutinize the implications of spillovers and strategic diversification for suppliers through changes in income (of household) and bargaining positions, factors which have been cited as critical to better understanding strategic diversification and upgrading (Barrientos et al 2016a). Previous work has found that strategic diversification could enhance both income and bargaining ability of suppliers (ibid). Spillovers could play a key role here, with knowledge spillovers from GVC participation suggested to lead to increasing income and bargaining potential for actors in regional markets (Pietrobelli and Rabellotti 2007). Moreover, farmers supplying to GVCs have been found to transfer knowledge, technology and productivity spillovers to their production of crops which are not certified or destined for global export markets, ultimately generating more income (Minten et al. 2009). Strategic diversification and spillover effects may thus potentially lead to economic upgrading - product (better quality produce) and process (improved practices used) - as well as social upgrading for different actors in the RVCs.

This study identifies different interactions of RVCs with GVCs. The first 'opportunistic spillover' interaction occurs when produce is rejected from GVCs for not meeting standards, leading suppliers i.e. producers (farmers, primary marketing organizations (PMOs) or co-operatives ${ }^{3}$ ) and

\footnotetext{
${ }^{3}$ In a co-operative, farmers pool their resources in activities such as extension services or production as they can reap economies of scale at a community level (within the organized farmer group).
} 
intermediaries (brokers, registered marketing agents ${ }^{4}$; and exporters ${ }^{5}$ ), to opportunistically seek regional buyers (regional supermarkets, local wet markets) to sell spillover produce in regional markets, and thus strategically diversify. This leads to the development of an 'opportunistic RVC' wherein suppliers earn more income, and have better bargaining position with both GVC and RVC buyers, as opposed to suppliers who only sell into GVCs. Subsequently, opportunistic spillover interactions have evolved into a more targeted form which is independent from GVCs, leading to a 'targeted RVC' wherein suppliers effectively downgrade by producing specifically for regional buyers through meeting regional private standards. Although not as directly engaged with GVCs, such supply may still benefit from knowledge spillovers from GVCs and also new skill acquisition from services provided by local governments and NGOs. Although initially occurring sequentially, opportunistic spillover and targeted RVC interactions are now time-invariant, elucidating to the fact that they also happen independently of each other or even as simultaneous hybrid (both opportunistic spillover and targeted) interactions forms, which I will discuss subsequently in the article. These interactions and related RVCs have implications for economic and social upgrading, which are studied through earning potential of suppliers and changes in their bargaining position. This more nuanced understanding of the expansion of RVCs, and how it relates to GVCs, will now be empirically elaborated through a case study of Kenyan FFV.

\section{Case context: Kenyan horticulture}

Fruits and vegetables are one of Kenya's foremost foreign exchange earners (HCDA 2012), having contributed 33\% of agricultural GDP in 2013 (World Bank 2015) and having grown at a compound rate of $10-12 \%$ per annum from 2003-2013 (ITC 2014). It is estimated that $10 \%$ of FFV production is exported, but it contributes to over $80 \%$ of total FFV revenues (Interview: Government official, $18^{\text {th }}$ November 2014, Nairobi) and is thus a critical income stream for the country. However, with over $90 \%$ of FFV production sold to the regional market (Evers et al. 2014; Tschirley et al. 2004), the regional dynamics of FFV markets, must be examined. In this paper, Kenyan FFV GVCs are governed by international lead firms and Kenyan exporters while RVCs have two main buyers which are national supermarkets and buyers in local wet markets.

\section{A) Commodity Selection}

Avocados and French beans were chosen as cases to understand the processes of interactions of actors in RVCs with GVCs for two reasons. First, as both crops are exported as well as consumed regionally, they are therefore appropriate for understanding how the expansion of RVCs relates to GVCs. Secondly, the crops convey two different aspects of regional consumption which are explained

\footnotetext{
${ }^{4}$ Registered marketing agents are brokers who are registered with the Horticultural Crops Directorate at local or national levels, as opposed to brokers who act as individuals and do not need to give traceability reports of produce to any government body.

${ }^{5}$ Kenyan firms who obtain a license (provided to them after vetting by the Horticultural Crops Directorate) to export produce to EU supermarkets.
} 
in greater detail in this section. In the case of avocados, the type of avocado currently consumed changed from indigenous varieties to a new export variety (Haas), thus leading to product differentiation in regional markets; while for French beans, a new product was introduced that was not previously consumed in the country.

Avocados comprised 75\% of all fruit exported from Kenya and 14\% of total FFV exports in 2013 (Oduol et al. 2013). Consumed in Kenya since the early 1950s, only local varieties of avocados (e.g. Pueble, Duke and G6) were initially produced in the country. From the 1970s onwards, however, European buyers began to encourage Kenyan producers to plant different varieties of avocado, such as Fuerte and Haas, to meet European consumer preferences. Approximately $85 \%$ of the suppliers of avocado in Kenya are small-medium scale farmers and farmer groups, the remainder large scale farmers and Kenyan exporting companies who own their own-farms (Wasilwa et al. 2006). In terms of revenues, Kenyan avocados are estimated to be split approximately 50:50 between export and domestic markets (Interview: Government official, $24^{\text {th }}$ November 2014, Nairobi). For the survey, as Murang'a county was the largest producer of avocados in 2013, 128 of the 166 avocado farmers were sampled from this region and the remaining (38) from Meru county (the third largest producer of avocados in 2013).

Approximately half ( 82 farmers) ${ }^{6}$ of the avocado farmers [in the sample] sold to GVC buyers (Kenyan export firms or international supermarkets). Of these farmers, about 83\% (68 farmers) simultaneously sold a substantial portion (on average a quarter of their total avocado production) to RVC buyers (regional supermarkets and wet/wholesale markets), thus participating in overlapping chains. Only about 17\% (14 farmers) of GVC farmers did not diversify their end markets; that is they sold all their produce to a GVC buyer.

The second crop, French beans, was introduced to Kenya by European retailers in the mid-1970s. Currently the largest African exporter of French beans to the European market (Evers et al. 2014), beans are crucial for Kenya's economy and comprise almost 60\% of total FFV exports (ITC 2014). Estimates have suggested that 50,000 small-scale farmers grow French beans in Kenya and are responsible for over $80 \%$ of total production, the remainder being supplied by Kenyan exporterowned farms and large farmers (SNV 2012). Interviews revealed that French bean production began as export supply for GVCs, but domestic demand has increased considerably, especially from urban supermarkets and regulated wholesale markets (Interviews: Supermarket sourcing managers A-D, November 2014- January 2015, Nairobi). Of the French bean farmers sampled, 82 of the $136(60 \%)$ were from Meru County (the second largest producer in 2013), and the remaining 54 (or 40\%) from Murang'a County (the third largest producer in 2013).

\footnotetext{
${ }^{6}$ The remaining $50 \%$ of the farmers sold to local markets (regional supermarkets and traditional wet markets) and did not sell into any other end market.
} 
Approximately two thirds (90 farmers or $66 \%$ of the sample) ${ }^{7}$ of the French bean farmers surveyed sold to GVC buyers. Of these, about 63\% (56 farmers) of the French bean export farmers overlapped chains by also selling a considerable volume of their production (on an average $28 \%$ of their total) to RVC buyers. Only 37\% (34 farmers) of the French bean export farmers remained undiversified - selling solely to GVCs. Avocados and French beans are ideal crops that will facilitate in unearthing the nuanced understandings on the expansion of RVCs in Kenya.

\section{B) Regional FFV markets: Kenyan supermarkets}

Supermarkets (used here to also refer to hypermarkets, discount outlets and convenience stores) in Kenya have domestic, rather than foreign-owned, roots. Larger Kenyan chains, such as Nakumatt, Uchumi, Chandarana and Tuskys, were founded in the 1960s, 1970s and 1980s, followed by smaller chains such as Naivas and Zucchini in the 1990s. These chains became fully operational by the mid-1990s, around the same time when FFV exports began to grow dramatically (English et al. 2004). Together these six retailers are estimated to control over $95 \%$ of all Kenyan supermarket FFV sales, which is about $7-8 \%$ of total domestic FFV sales (Interview: Supermarket sourcing managersB,C,F December 2014 - January 2015, Nairobi). The proliferation of supermarkets in Kenya occurred in the early 2000s, as part of what Reardon et al. (2007) refer to as the 'third wave' of diffusion of supermarkets in developing countries. Kenyan formal retail expanded from an insignificant niche market, which catered only to rich immigrants and local elites in the 1990 s, to over $20 \%$ of urban food retail by 2003 and 34\% in 2014 (Euromonitor 2015), by then accessible to middle and lower income consumers (Neven and Reardon 2004).

The number of supermarket outlets in Kenya has followed an upward trend, growing from approximately 60 in 2007 to 192 by 2014 (author calculations ${ }^{8}$ ), an increase of 200\%. Furthermore, revenue earned by the three largest supermarkets increased by $43 \%$ between 2007 and 2014, a substantially faster growth rate than the more saturated supermarkets in Europe (McKinsey 2015). FFV sales in Kenya have increased from a minor share of 1-2\% of supermarket turnover in 2007 to 5 $10 \%$ in 2015 . Supermarkets reported in interviews that they expect this figure to continue increasing and are hence making FFV one of their priority segments (Interviews: Supermarkets- A, B, C, D: $18^{\text {th }}$ $24^{\text {th }}$ March 2015, Nairobi).

\section{C) Regional FFV markets: Regulated and unregulated local wet markets}

Despite the rise of organized Kenyan supermarkets, middle and low income consumers still purchase from local wet markets, where over $90 \%$ of all domestic FFV production is sold (Evers et al 2014). Wet markets consist of wholesale markets, street vendors (hawkers) and local kiosks. Over 95\% of wet markets are estimated to be unregulated and thus are not monitored to check for quality or

\footnotetext{
${ }^{7}$ The remaining $34 \%$ of farmers sold to local markets (regional supermarkets and traditional wet markets) and did not sell into any other end market

${ }^{8}$ Deloitte, 2011; Dihel, 2011, Mahajan, 2011 and company annual reports 2016 of Nakumatt, Tuskys, Uchumi, Naivas, Chandarana.
} 
hygiene requirements (Interview: Government official-C, 13th March 2015, Nairobi). However, the last decade has seen an emergence of wet markets regulated by municipal authorities (e.g. City Park market in Nairobi) which have increasingly become more structured and offered better quality (compared to unregulated wet markets) and variety of produce that caters to middle-upper income groups (Interview: Wholesaler-A, $12^{\text {th }}$ November 2014, Nairobi).

\section{The interactions of RVCs with GVCs}

This section explores the dynamic interactions of RVC actors, including suppliers, buyers and consumers, with GVCs and the implications for supplier participation (through strategic diversification) and upgrading (bargaining position and income changes). Through an examination of avocados and French beans, the two types of interactions, opportunistic spillovers and targeted regional production, are elaborated

\section{A). The opportunistic spillover interaction and opportunistic RVCs}

A crucial step in understanding the emergence of opportunistic spillover interactions for RVCs is the context of suppliers' participation in GVCs. Kenya's growth in FFV exports has been driven by supplying European supermarkets, and thus through participation in buyer-driven GVCs (Dolan and Humphrey 2000). In order to access such global markets, producers have to adhere to stringent standards, such as GlobalGAP (a good agricultural practice and food safety standard), along with international government regulations (Henson and Humphrey 2010; Ouma 2010). Initially introduced as voluntary requirements in the mid-1970s, such standards have become 'defacto mandatory', thus creating barriers to entry to European markets (Gibbon and Ponte 2005). Although a struggle, the fear of rejection of produce and exclusion from the significantly higher revenues available from Northern exports has pushed many Kenyan farmers to replace their indigenous practices and learn and adopt EU-compliant good agricultural practices (GAPs).

To participate in GVCs, i.e. to be able to sell to European retailers, Kenyan farmers have switched their type of produce. While local avocado varieties are fibrous, have a soft outer covering and short shelf life (Wasilwa et al. 2006), the most common varieties consumed in European markets are Haas and Fuerte, which are smoother, creamier and have longer shelf lives. Thus local avocado varieties have mostly been replaced with export varieties demanded by European consumers, which had not previously been produced or consumed locally. Survey data illustrates that over $85 \%$ of the 155 farmers surveyed in Murang'a County had at some stage replaced old varieties of avocados with export varieties. Meanwhile, many farmers who had previously grown cereals and local vegetables for local markets and subsistence ${ }^{9}$ began in the 1970 s to commercially grow French beans, which were introduced by European retailers in collaboration with Kenyan exporting companies, for international

\footnotetext{
${ }^{9} 70 \%$ of the French bean farmers surveyed grew cereals like wheat and $30 \%$ grew vegetables such as tomatoes and kale.
} 
markets. Some of these French bean producers reported that they earned considerably more on average (one estimate was for over five times) than they did when selling cereals (e.g. Interview: Farmer 4, $29^{\text {th }}$ February 2015, Meru). For both avocados and French beans, many interviewees reported that the Ministry of Agriculture and county governments only began supporting planting of export products after they found that these crops were contributing significantly to state income (Interview: Government official-C, $13^{\text {th }}$ March 2015; Exporter A-C, $1^{\text {st }}-20^{\text {th }}$ January 2015, Nairobi). This perspective suggests that the government played a small and reactive role in the initial development of these markets.

The post production 'sorting' of avocados and French beans, which ultimately determines if it 'makes the grade' to be sold in GVCs, is a crucial stage which has inadvertently contributed to the expansion of RVCs. Exporters or trained individuals sort produce into multiple grades (usually 1, 2 or 3 ) and sizes. Grade 1 is compliant with international standards and is procured by exporters. Produce samples are sent to Kenya Plant Health Inspectorate Service (KePHIS) for residue testing, before being packed and shipped to Europe. Grade 1 can also be purchased by intermediaries and then sold to exporters. Rejection of Grade 1 produce can occur at two stages- first by exporters and second at KePHIS. On average about $15 \%$ of grade 1 product is rejected (author survey) and the remaining produce gets relegated to grades 2 and 3. The rejects of Grade 1 are returned to the farmers or intermediaries by exporters about two weeks from the date of purchase.

Suppliers in GVCs have begun participating in regional markets through selling rejected grade 1, in addition to grade 2 and 3 produce. Hence, 'produce spillovers' occur, with export quality Grade 1 rejects along with grade 2 and 3 have 'spilt' into regional markets. Produce spillovers are special cases, which can only occur for non-indigenous or differentiated commodities which are grown in an intention to adhere to international standards and supply global markets. Interviews with different suppliers suggested the primary motivation to sell spillover produce was opportunistic, wherein the main focus was to offload rejected produce and maximize earning potential through regional sales, rather than throw away the rejected produce or feed it to cattle (Interviews: Cooperatives-A, B, $17^{\text {th }}$ February 2015, Murang'a). Thus a clear overlap is present, with suppliers simultaneously selling to both GVCs and RVCs. An inadvertent spillover of international GAPs into regional supply can take place by virtue of produce spillovers from GVCs.

GVC suppliers, in order to push Kenyan consumers to purchase a higher volume of spillover produce of French beans and avocados, began marketing the quality improvements, as well as health and nutritional benefits of spillover produce. Numerous seminars were held in churches and market places. For example, exporters, associations like Fresh produce exporters association of Kenya (FPEAK) and national and sub-national government officials held 'farmer knowledge meetings' where they trained farmers in good practices and discussed benefits of consuming avocados (Interview: Association-A, 30 ${ }^{\text {th }}$ October, 2014; Exporter-D, 22 ${ }^{\text {nd }}$ March 2015, Nairobi). Thus, suppliers from GVCs opportunistically interacted with regional buyers, leading to 'spillover effects' 
in regional markets, by introducing new and differentiated spillover products with improved quality. Interviews suggest that the produce spillover effect has continued to allow export quality produce to gradually infiltrate regional retail (Interviews: Wholesaler A, Exporter C, Farmers-F, G, $16^{\text {th }}-28^{\text {th }}$ January 2015, Murang'a/Meru).

\section{A.1). Opportunistic spillovers in local wet markets}

Spillover produce began entering local wet markets in the late-1970s, and has experienced continuous growth in demand ever since. Figure 1 maps the sourcing processes followed in local wet markets (including regulated/unregulated wholesale markets, street vendors and kiosks). The dotted line delineates the flow of French bean and avocados between suppliers, i.e. producers, intermediaries and exporters, while the solid line indicates the flow of products from GVC suppliers to the regional market. Spillover produce enters wholesale markets through GVC suppliers after all the produce intended for, and which has met the requirements of, the GVC market has already been sold.

\section{Figure 1}

With wholesale markets and street vendors sprawled across the country and reaching both low and middle income groups, spillover produce has spread widely. Interviews with wholesalers and kiosk owners confirmed a visible shift in consumer preference for the spillover produce. One wholesaler elucidated about growing market demand and a frequent customer to that wholesaler explained why demand has increased:

"People who come buy my products ask for the creamy variety of avocado and don't want the old fibrous variety anymore. I have to throw away some of the local stock. Everyone who is buying the tasty avocado is willing to pay me more... I make $0.5 \mathrm{Ksh}$ more for every fruit I sell." (Wholesaler A, $21^{\text {st }}$ November 2014, Nairobi)

"My friends saw me prepare new dishes for my family with French beans. I made it in the way my shopkeeper told me. It is very healthy and tasty...Now all my friends want to cook this for their husbands." (Customer A, $21^{\text {st }}$ November 2014, Nairobi)

Even in regions where local varieties of avocado are still predominantly growing, consumers appear to have begun demanding 'improved' (spillover) produce, as aptly explained by a wholesaler in Meru:

"Nairobi avocados [used as a synonym for export variety avocados] are not easily available; we source through brokers from Nairobi. Our customers who have travelled 
central region and eaten those avocados...want the same quality here... so we have been getting them for the last 30 years." (Wholesaler F, $6^{\text {th }}$ December 2014, Meru)

A distinct shift in product choices of consumers occurred, based on improved taste, quality, product variety and, in some cases, health benefits, due to opportunistic spillover interactions of GVC suppliers with RVC local wet market buyers. The shift in consumer preferences was not only limited to the middle income groups, as has been discussed in other cases (e.g. Hughes et al. 2015), but extended to low income groups who appear to prefer spillover produce. Local consumers are not necessarily concerned with product traceability. Rather the demand for new and differentiated spillover produce is driven on the basis of quality, visual appeal of the product and supplier recommendations, revealing that suppliers are able to control the quality of product into local wet markets in opportunistic spillover interactions.

\section{A.2). Opportunistic spillovers in Kenyan supermarkets}

The other buyers of spillover produce in RVCs are regional supermarkets. The sale of FFVs in supermarkets in Kenya began in the late-1970s, with companies like Nakumatt taking the lead. FFV segments started as loss leaders but, between the 1990s and mid-2000s, the average earnings of FFV increased to $5-10 \%$ of total regional sales (Neven and Reardon 2006). This rise in earnings was partly because, from the late-1990s onwards, higher margin spillover produce of avocados and French beans began being sourced by Kenyan supermarkets to cater to middle-upper income groups, who demand this produce. This is depicted in figure 1, which illustrates that spillover produce primarily enters regional supermarkets though GVC suppliers (mostly intermediaries, exporters and some producers), through large wholesalers and by regional supermarkets' direct procurement from wholesale markets.

"Most of my produce used to come [in the 1990s] from good brokers and exporting companies, but I also sometimes went to the local market [wholesalers and familiar kiosks] to buy the rest of my French bean requirement" (Sourcing manager: B, $11^{\text {th }}$ December 2014, Nairobi).

This indicates that the procurement systems of supermarkets were similar to that of wholesalers in local wet markets, wherein GVC suppliers usually visited individual stores to supply produce or were at times approached by sourcing managers themselves (Interview: sourcing manager B $11^{\text {th }}$ December 2014, Nairobi).This was very common in larger chains such as Nakumatt and Uchumi between the $1990 \mathrm{~s}$ and early-2000s, and is still a prevalent practice with smaller supermarkets and other store formats such as convenience stores. Most suppliers of avocados and 
French beans came from Murang'a and Meru counties, with good road networks to locations where supermarkets were located.

The volume and quality of spillover produce entering regional supermarkets through opportunistic spillover interactions is largely dependent on GVC suppliers for two reasons. Firstly, supermarkets that wanted to procure French beans or avocados could only do so from GVC suppliers, as they were the only producers of those commodities. Secondly, GVC suppliers marketed export varieties to supermarkets by holding seminars in churches and demonstration farms, promoting awareness of the improved quality over local varieties and higher returns they could earn from customers (Interview: PMO-C $18^{\text {th }}$ February 2015, Murang'a).

The strength of the GVC suppliers is abetted by the fact that supermarkets that source this produce do not yet have efficient grading systems in place to check produce quality (many supermarkets used untrained employed to grade produce visually) and instead rely on the word of suppliers. Moreover, they also have not enforced traceability requirements, primarily as FFV segments are still less than $10 \%$ of overall sales in these supermarkets. Thus most traceability and grading requirements were similar to local markets. However, these supermarkets have attempted to competitively differentiate themselves from local markets through value addition and 'slightly better' visual standards for instance by selling cut and packed French beans as a means to offer greater product choice. The spillover effect thus influenced regional supermarket customer preferences, especially on quality and taste.

In a nutshell, the first type of interaction of RVCs with GVCs came through spillover effects which were opportunistic and 'accidental' rather than 'intended'. That is GVC suppliers found that they could sell excess produce to regional markets, thereby strategically diversifying their market portfolio and simultaneously participating in both value chains. Thus this has led to the development and expansion of opportunistic RVCs.

\section{A.3) Opportunistic spillover interactions and opportunistic RVCs: Implications for suppliers}

The opportunistic interactions involved two major types of implications for suppliers. The first relates to their ability to strategically diversify; and the second to the outcomes for income and bargaining positions. As elucidated, in opportunistic RVCs, suppliers are strategically diversified and control the volume and quality of the produce going into regional markets.

In interviews, suppliers, mainly farmers and farmer groups, were asked whether being strategically diversified into RVCs, in addition to their participation in GVCs, enabled them to earn more income and whether they felt they were able to better bargain for higher prices with both their buyers as a result. Almost all the farmers claimed this to have been the case (Interviews farmers 1-8, farmer groups-A-D, October-February 2014-15, Meru/Murang'a). Table 1 provides survey evidence that farmers supplying both exporters and regional supermarkets in 2014-15 earned 26.6\% more income since diversification as opposed to only a $13.3 \%$ increase earned by farmers who only 
supplied export markets. Farmers supplying both export and local wholesalers/wet markets were also found to earn $16.85 \%$ more income since diversification, which is still $3.55 \%$ more than nondiversified farmers. The survey indicates that on average farmers from these regions have been diversified for the last 3-5 years.

\section{Table 1}

In opportunistic RVCs, regional buyers are relatively weak in terms of bargaining position, as they are dependent on spillover produce from GVC suppliers. Of farmers who diversified from GVCs to sell to regional supermarkets, $45 \%$ reported experiencing an increase in their ability to bargain for better prices with both their buyers. Little change in bargaining position was reported for farmers who have diversified from GVCs to selling into wet and wholesale markets. A plausible reason for poor bargaining position of regional supermarkets is that they are relatively new in the FFV segment and yet to establish their own sourcing and distributional facilities. Trust and familiarity with suppliers (see Murphy 2006) were pointed to by one interviewee as key for some regional supermarket sourcing networks:

"We bought from all our good and loyal suppliers and friends; we know they would not cheat us with bad quality. Also many of our friends supply to big exporters, we know the produce is good" (Sourcing manager G, 15th January 2015, Nairobi)

In sum, opportunistic RVCs began the trend from the 1990s for strategic diversification, leading to improving quality of produce entering regional markets and creating positive externalities for diversified export farmers.

\section{B). Targeted supply interactions and targeted RVCs}

In the early-2000s, a dynamic structural shift emerged in supplier-buyer-consumer interactions wherein some RVC buyers forged direct "targeted" links with suppliers, rather than procuring spillover produce from GVC suppliers. This change was mainly because of the rapid growth of regional markets. Kenyan supermarkets, between 2009 and 2014, grew at a compounded rate of approximately $30 \%$ (Interview Donor-C, $28^{\text {th }}$ October 2014, Nairobi) fuelled by a $10 \%$ increase in per capita income and $41 \%$ rise in the urbanization rate during the same period (World Bank 2015). Since the mid-2000s, grocery has become one of the fastest growing segments for supermarkets, especially for chains such as Nakumatt, Uchumi, Tuskys and Naivas. For example, Nakumatt's and Tuskys' volumes and values per unit of avocados and French beans grew by over 100\% from 2003 to 2014 (Interview: Supermarket CFO-A, $20^{\text {th }}$ November 2014, Nairobi).

The targeted interaction caused a shift in the participation of suppliers into 'targeted RVCs'. Many suppliers who had struggled to continue to supply to GVCs due to inhibitive certification costs, 
effectively downgraded ${ }^{10}$ by switching to RVCs given lower production costs. Furthermore, farmers could use the training they received on EU-compliant GAPs to adhere to newly emerging regional standards, in effect causing a 'knowledge spillover' from a GVC to a RVC. On average, the survey finds that farmers who shifted from selling to international retailers to regional supermarkets, continued to follow about $70 \%$ of the GAPs that they learnt while participating in the GVC. Thus this set of suppliers chose to downgrade by not participating in GVCs and changed to new target markets regional supermarkets and local wet markets. Thus, they were also no longer strategically diversified as they only sold to regional markets. One farmer explained the benefits of selling to regional markets:

\begin{abstract}
"I want to sell to supermarkets and my wholesaler friends. I get better prices from them and less fuss... much better than the hassle of selling to European markets"'(Small-scale farmer-7, $29^{\text {th }}$ October 2015, Murang'a).
\end{abstract}

The rapid growth of regional markets also attracted another set of producers, who had not previously been participating in avocado or French bean GVCs, into RVCs. Many of these producers grow exclusively for regional supermarkets or local markets because of the lower entry barriers, flexible standards and higher margins of these markets compared to global markets (Interviews: PMO-A, $16^{\text {th }}$ February 2015, Meru). Furthermore, many of these producers benefited from 'knowledge leakage spillovers', through learning and imitating GAPs from farmers experienced at supplying GVCs. Such spillovers have been facilitated by the close proximity of these farmers to GVC farmers (Interview: Farmer group-C, $18^{\text {th }}$ February 2015, Meru). Other producers seeking to benefit from opportunities in RVCs, but who had not been exposed to knowledge leakages, have attended special training sessions (organized by NGOs and county governments) to better understand GAPs required for regional markets (Interview: Farmer group-F, $20^{\text {th }}$ February 2015, Meru). One member of a farmer group explained:

"I used to sell cows before but, now, because of high supermarket demand, I decided to start growing French beans and now I make much more money. I don't want to sell to Europe. It is too costly and difficult." (Member farmer group F, $20^{\text {th }}$ February 2015, Meru)

Hence, the second type of interaction involved the development of 'targeted' regional supply which moves beyond opportunistic spillover interactions. While in an opportunistic spillover interaction, GVC suppliers diversify by participating in both chains, here suppliers are operating within, and focus only on supplying, regional markets through targeted RVCs. As illustrated in Figure 2, two main types of suppliers have emerged - first, chain downgraded

\footnotetext{
${ }^{10}$ Gibbon and Ponte (2005:138) define downgrading as "relegation to less remunerative and/or secure end-market segments or channels" and subsequent work suggested South African wine production to be an example of such a process (Ponte and Ewert 2009).
} 
farmers, PMOs, exporters and brokers who have stopped participating in GVCs, second, farmers who were marginalized from GVC markets or did not previously grow avocados or French beans - and are now participating in targeted RVCs. These suppliers have made direct connections with regional supermarkets through adhering to their standard requirements.

Figure 2

In order to continue to attract customers, regional buyers have focused their efforts on maintaining product quality and differentiation, which has led to the development of regional private standards. These RVC standards were an aftermath of opportunistic RVCs and a reaction to changed consumer demands. Local wet market buyers participating in opportunistic spillover interactions only stipulate the need for visual standards, pertaining to ripeness and size of the fruit. However, as customer demand and ability to pay for better quality spillover produce increased, local wholesalers and vendors began attempting to improve visual standards to also include additional criteria such as colour, shelf-life and black spots on the avocados and the length, colour, shape and insect bite marks on French bean. Thus, standards in local wet markets started evolving from the late-2000s, especially in managed (regulated) wholesale markets. Many of the wholesalers, kiosk owners and street vendors have started grading produce for the regional market based on their experience and customer requirements. For example, one interviewee explained:

"My clients are mostly from Eastlands [a low income area of Nairobi] ... and they keep asking for the good avocado, which is tastier and [they] do not want to buy the local fibrous variety anymore. I now only buy from big brokers who give me good quality and colour so I sell to customers at a big profit...it is not like before, customers are smart now....". (Kiosk owner D, $13^{\text {th }}$ November 2014, Nairobi)

Regional supermarkets have also developed private standards to maintain quality, meet consumer expectations and differentiate themselves from their competitors (local markets, other formats of retail and other supermarkets) (Interviews: Supermarket sourcing managers-F,B,C, $17^{\text {th }}$ December 2014January 2015, Nairobi). In targeted RVCs, some regional supermarkets have maintained quality through selecting 'preferred suppliers' who they source from, which has also augmented the traceability of products. Certain larger supermarkets such as Nakumatt prefer their suppliers to be certified by locally benchmarked standards such as KenyaGAP, a standard benchmarked to GlobalGAP (Evers et al. 2014), while others are more visual and flexible with their standards. Although regional supermarket standards are less stringent than European requirements, regional supermarkets are increasingly implementing higher levels of quality control, as one sourcing manager described: 
"Consumers today are demanding better quality for their produce at lower prices... We have to pay special attention to grading our produce and maintain traceability records so that we know who is a good supplier and who is not.... this saves us time and helps build reliable supply. We never needed to do traceability before." (Sourcing manager D, $10^{\text {th }}$ December 2014, Nairobi)

Table 2 delineates changes in sourcing strategies, distribution systems and traceability of the large supermarket chains, which have direct linkages with suppliers and expect adherence to their private standards. This is contrary to opportunistic RVCs wherein some supermarkets do not have any explicit regional distribution systems or sourcing strategies or standard requirements. Most of what are now the larger supermarkets (Nakumatt and Tuskys) had opportunistic spillover interactions with GVC suppliers prior to the 2000s. Subsequently, they established centralized distribution systems, where all produce is collected at one spot and graded by a specialized company (e.g. Fresh n Juici). In contrast, for Chandarana, the procurement system is 'in-store' which means that suppliers visit specific stores to sell their produce to supermarket sourcing teams, which is graded in-store by experienced professionals. Naivas and Uchumi use both in-store means of procurement as well as outsource their supply requirements to intermediaries such as specific brokers, wholesalers or sourcing companies. Thus, the sourcing strategies used are distinct from those discussed in section A2 for opportunistic spillover interactions.

\section{Table 2}

The Kenyan state has also facilitated the growth of regional standards, by shifting from a small and reactive role in the opportunistic spillover RVCs to a more active role in the mid-2000s. Although the nodal government institution, the Horticultural Crops Directorate (HCD), had initiated a GAP code of conduct for all horticultural crop producers in 1995, interviewees reported that they only began legally enforcing these codes of conduct from the mid-2000s. Furthermore, the HCD also enforced Kenyan FFV exporters, brokers and PMOs to mandatorily register with them. These government changes enabled regulating and checking of the quality of produce in local markets and encouraged regional buyers and intermediaries to only procure from producers who adhered at a minimum to these standards (Interview: Government official-C, $18^{\text {th }}$ December 2014, Nairobi).

The targeted interaction process thus involved a shift in the quality requirements in the RVC, with a new set of standards established by regional buyers along with changes in their sourcing systems and traceability requirements. Thus spillover produce is no longer good enough to sell to some supermarkets or local wet markets in targeted RVCs. The importance of standards was described by one sourcing manager: 
"15 years ago we used to procure avocados from the local wholesale market or through brokers who would buy any produce... some were even rotten... But the last few years has been a complete transformation of the market. Our sellers are aware of standards and they come with very good produce." (Sourcing manager-G, $15^{\text {th }}$ January 2015, Nairobi)

Thus some RVCs evolved due to more 'targeted interactions' as a result of direct connections between RVC suppliers and buyers, as opposed to the more 'accidental' links in opportunistic spillover interactions. This is not to say that opportunistic spillovers need to be phased out before a targeted interaction occurs. Opportunistic spillover interactions are still common in Kenya with smaller supermarkets and in local wet markets. However as RVCs expand and regional buyers become more powerful (e.g. large supermarket chains), targeted interactions have become more prevalent. This is because targeted supply involves the growth of regional standards, which have been applied by regional buyers beyond spillover commodities like French beans and avocados to indigenous crops such as Sukuma wiki and Managu (types of collard greens). Interviews with sourcing officers of four main supermarkets suggested that this has been done in order to maintain reputation and have a competitive edge over other supermarkets and local markets.

\section{B.1) Targeted interactions: Implications for suppliers}

The higher margins earned through selling to regional markets were frequently cited by producers as their main motivation to sell into regional markets. Table 3 shows the implications for suppliers, specifically farmers participating in the targeted RVC. Farmers who have chain downgraded (i.e. who used to, but no longer, sell to international retailers) reported experiencing on average a $13.33 \%$ increase in income since leaving the GVC and $19 \%$ have reported an increase in their ability to bargain for a better price with regional supermarkets. Similarly, the survey suggests that farmers who have newly entered RVCs have experienced over a 50\% increase in incomes and $10 \%$ of farmers indicated an improvement in their bargaining position compared with their previous livelihoods. The growth of regional markets has thus not only been a new source of employment, but has also minimized the opportunity cost of downgrading and not being strategically diversified.

\section{Table 3}

\section{C). Key characteristics and implications of opportunistic and targeted RVCs}

Table 4 (column 3) highlights the key interaction characteristics of opportunistic RVCs and their implications for RVC buyers and GVC suppliers. One of the main interaction characteristics is mode of product type, which in this case is spillover produce and the mode of sourcing of regional buyers is through GVC suppliers. The mode of practice diffusion is through spillover practices that emerge as a 
virtue of spillover produce entering regional markets. Further traceability in these interactions is not required and there are no standards that are mandatory or required. Suppliers in this case have many buyers they can sell to and thus are highly strategically diversified. In terms of the implications for suppliers, the balance of bargaining position (a proxy for who controls quality of produce and the ability to negotiate for more money for their produce) and changes in income (whether suppliers were able to increase rents by strategically diversifying) appear to be favourable to GVC farmers who are strategically diversified as evidenced in table 1.

\section{Table 4}

Column 4 brings out the characteristics of targeted interactions and the implications for RVC suppliers. For instance, the mode of product type is customized as per regional buyer requirements, unlike spillover produce in opportunistic spillover interactions. The mode of sourcing is through direct linkages with RVC suppliers and governance mechanisms include adhering to explicit standards of regional buyers. Traceability in these interactions is also increasingly important relative to opportunistic spillovers. Farmers are no longer strategically diversified. In terms of the implications for suppliers, the bargaining position of regional buyers is stronger relative to suppliers, as RVC buyers set standards and determine quality levels. However, producer incomes have increased since downgrading or newly participating in RVCs.

\section{D). Beyond opportunistic spillover and targeted interactions: Hybrid interactions}

The two interactions identified here are not mutually exclusive. Although they may have evolved sequentially, suppliers can now aim to participate in either type of RVC at any point of time depending on when they choose to downgrade, upgrade or diversify. These are dynamic processes that occur depending on the strategic decisions and interactions buyers and suppliers undertake and are not time-specific.

"Hybrid interactions" may also exist with a mix of the interaction characteristics of opportunistic spillovers and targeted interactions in RVCs, which enable strategic diversification. Until now strategic diversification has only been discussed for 'spillover produce', however suppliers may choose to intentionally produce for specific markets and participate in multiple chains simultaneously. For instance, some suppliers began interacting with RVCs through 'targeted' processes such as the case of a Meru-based PMO of 4,500 farmers. They sold French beans and oranges to regional supermarkets by adhering to private supermarket standards. Simultaneously, they also began selling packaged and processed versions of these products to exporters and processing companies, thus strategically diversifying into GVCs and using a different set of standards for export markets. Hybrid interactions can also occur when producers start out by participating in opportunistic RVCs, and move to more 'intended' strategic diversification. For example, farmers observing the higher margins and lower standard requirements in regional markets may decide to grow French beans on part of their land to sell directly to regional supermarkets using supermarket standards, while export quality 
produce is grown on the remaining land to sell to exporters with international certifications. Farmers in such a situation have customized mode of product type, use explicit standards that each market demands and are strategically diversified. Many farmers in Meru and Murang'a counties reported to undertake hybrid interactions as they feel that 'intentionally strategically diversifying' spreads their risk and enables increasing incomes. Figure 3 illustrates that suppliers in RVC may be situated within hybrid interactions if they have attributes of both opportunistic spillover and targeted interactions. Recognising these mixed attributes provides a more nuanced approach to understanding the expansion of different RVCs and co-existence of RVCs and GVCs.

\section{Figure 3}

\section{Discussion and Conclusion: Interactions of RVCs with GVCs and applications}

In the case of avocados and French beans in Kenya, the dynamics of RVC expansion have been actively shaped by interaction with GVCs. This paper identifies two main types of interactions, first the 'opportunistic spillover' wherein suppliers in GVCs strategically diversified by selling rejected produce, marketed as export quality, to regional buyers, which leads to the development of 'opportunistic RVCs'. With this improved quality of produce on offer, consumer product choices slowly changed in regional markets. Subsequent to the initial opportunistic RVC (which mostly occurred between the late 1970s and early 2000s), rather than continuing to export to global markets or supply multiple value chains simultaneously, many producers began participating in the second type of interaction by downgrading and 'targeting supply' to regional markets from the mid-2000s onwards, to form targeted RVCs. While these are ideal types of interactions, RVC suppliers may also be involved in hybrid interactions, involving characteristics of both opportunistic spillovers and targeted interactions. It is important to note that opportunistic spillovers, targeted supply and hybrid interactions are not necessarily temporal nor do they necessarily happen sequentially, rather they are dynamic and continuously occurring processes that are dependent on the trajectories of specific actors in the value chain and the choices that they make in different market contexts.

A few caveats are warranted. First, the types of interactions identified here may be more likely to be observed where the geographies of trade are first North-South and then evolve to SouthSouth. In a sense the expansion of RVCs can be viewed as an outcome of the spillover effects of globalization. Second, the types of interactions may best fit 'short' value chains (such as FFV) which are 'buyer-driven', because short chains have relatively few nodes between production and final consumption and thus suppliers are more likely to know who their end buyers are. Future research could explore the broader applicability of the types of interactions in the context of RVCs in other sectors. 
The move from supplier driven-ness of opportunistic spillovers to more buyer-driven targeted supply interactions poses two diverging positions in debates on regional chain governance. On one hand is a positive story of increased participation and expansion of RVCs due to lower entry barriers, with little by way formal private or public standards demanded by regional supermarkets and wet markets, and higher margins for suppliers. On the other hand, a possibility emerges of a new wave of marginalisation of farmers due to the growth of stringent regional standards in RVCs that become more established over time (a similar issue is highlighted in Pickles et al, 2016). The consequences of this could include loss of livelihoods, food insecurity, poverty and unemployment as faced by farmers excluded from GVCs, which can be explored by further research. Future work could also tease out further the governance dynamics within each of these interactions by engaging more deeply with GVC governance frameworks as discussed in Gereffi et al (2005).

When examining the uptake of standards, changes in processes of production and varieties of products as well as the income effect and bargaining ability, this paper has implications for both economic and social upgrading and downgrading. Albeit in a limited way, the analysis of strategic diversification and spillovers explicate that chain downgrading can lead to economic and social upgrading in targeted supply interactions. While in the case of opportunistic spillover interactions, strategic diversification can be considered as a form of functional and chain upgrading in relation to GVC suppliers. Additionally, the opportunistic spillover has aided in building more resilient livelihoods by enabling farmers to hedge their produce in different end markets. Further studies on upgrading could endeavour to comprehend how it differs for various stakeholders across both RVCs and GVCs in each type of interaction. The recognition of this will lead to a more nuanced understanding of upgrading in a changing market context.

Awareness of interactions has implications for the 'free-riding' debate as proposed by some scholars (e.g. Riisgard 2009; Barrientos et al. 2016a) who suggest that many GVC suppliers are able to use their expertise gained by supplying to EU (and implicitly other Northern) markets to enter regional markets. Albeit true, this research finds that this ability to 'free ride' varies according to the type of interaction with GVCs. While suppliers in opportunistic spillovers could 'free ride' on their ability to comply with international standards, many suppliers in targeted interactions do not have any previous certifications to 'free ride' on. Thus to assess supplier economic or social upgrading from participating in RVCs, generalizations cannot be drawn by 'just participating in GVCs', but rather the interaction with GVCs, and the evolution of the RVC, must be considered.

This work points to the importance for national and local policymakers of identifying the positionality of different value chain actors in different types of interactions (and RVCs) i.e. mapping the role of supply and demand side actors within the chain; thus creating, tailored economic, social and environmental policy initiatives. For instance, the evolution from opportunistic RVCs to targeted RVCs enabled emergence of new public governance structures such as the development of government national standards (HCD code of conduct for GAPs). The uptake of the HCD code of 
conduct has altered agricultural policy by helping farmers to learn GAPs and thus upgrade. Hence a deeper understanding of how RVCs relate to GVCs could help inform how initiatives could be tailored to the specific requirements of the dynamic, evolving regional and global value chains that constitute the contemporary global economy. 


\section{REFERENCES}

Barrientos, S., Knorringa, P., Evers, B., Visser, M. and M. Opondo (2016a) 'Shifting regional dynamics of global value chains: Implications for economic and social upgrading in African horticulture', Environment and Planning A, 48 (7), 1266-1283.

Barrientos, S., Gereffi, G. and Pickles, J. (2016b) 'New dynamics of upgrading in global value chains: Shifting terrain for suppliers and workers in the global south', Environment and planning A, 48 (7), 1214-1219.

Bergman, E. M. and J. Feser (2001) 'Innovation system effects on technological adoption in a regional value chain', European Planning Studies, 9(5), 629-648.

Dicken, P., Kelly, P.F., Olds, K. and H. Wai-Chung Yeung (2001) 'Chains and networks, territories and scales: towards a relational framework for analysing the global economy', Global Networks, 1(2),89-112.

Dolan, C. and J. Humphrey (2000) 'Governance and trade in fresh vegetables: the impact of UK supermarkets on the African horticulture industry', Journal of Development Studies, 37(2), 147176.

English, P., Jaffee, S., and J. Okello (2004). Exporting out of Africa: the Kenya horticulture success story. In Scaling Up Poverty Reduction: A Global Learning Process Conference. Shanghai. May (Vol. 25).

Euromonitor (2015) 'Grocery Retailers in Kenya' [Online] Available at: http://www.euromonitor.com/grocery-retailers-in-kenya/report [Accessed 5 Jul 2015]

Evers, B., Opondo, M., Barrientos, S., Krishnan, A., Amoding, F., and L. Ndlovu (2014) 'Global and regional supermarkets: Implications for producers and workers in Kenyan and Ugandan horticulture', Capturing the Gains Working paper 39: University of Manchester

Gereffi, G. (1994) 'The organization of buyer-driven global commodity chains: how US retailers shape overseas production networks', in G. Gereffi and M. Korzeniewicz (eds) Commodity Chains And Global Capitalism, Westport, CT: Praeger, 95-122.

Gereffi, G. (1999) 'International trade and industrial upgrading in the apparel commodity chain', Journal of international economics, 48(1), 37-70.

Gereffi, G., J. Humphrey and T. Sturgeon (2005) 'The governance of global value chains', Review of International Political Economy, 12 (1), 78-104.

Gibbon, P. and S. Ponte (2005) Trading down: Africa, value chains, and the global economy, Philadelphia: Temple University Press.

Guarín, A. and P. Knorringa (2014) 'New middle-class consumers in rising powers: Responsible consumption and private standards', Oxford Development Studies, 42(2), 151-171.

HCDA (2012) 'Horticulture Strategic Plan: 2009-2013'. [Online] Available at: http://www.hcda.or.ke/downloads/HCDA STRATEGIC PLAN 2009 - 2013.pdf [Accessed 12 Oct 2014]

Henson, S. and J. Humphrey (2010) 'Understanding the complexities of private standards in global agri-food chains as they impact developing countries', The Journal Of Development Studies, 46(9), 1628-1646.

Horner, R. (2015) 'A New Economic Geography of Trade and Development? Governing South-South Trade, Value Chains and Production Networks', Territory, Politics, Governance, 1-21,doi: $10.1080 / 21622671.2015 .1073614$.

Hughes, A., McEwan, C. and D. Bek(2015) 'Mobilizing the ethical consumer in South Africa', Geoforum, 67, 148-157.

ITC (2014) 'ITC Trade Map', [online] Available at:http://www.trademap.org/ [Accessed 3 Jan, 2014]

McKinsey (2015) 'The rise of the African consumer', [Online] Available at: http://www.mckinsey.com/global_locations/africa/south_africa/en/rise_of_the_african_consum er [Accessed 30 May, 2015]

Minten, B., Randrianarison, L. and J.F. Swinnen (2009) 'Global retail chains and poor farmers: Evidence from Madagascar', World Development, 37(11), 1728-1741.

Murphy, J. T. (2006) 'Building trust in economic space', Progress in Human Geography, 30(4), $427-$ 450.

Navas-Alemán, L (2011) 'The impact of operating in multiple value chains for upgrading: the case of the Brazilian furniture and footwear industries', World Development, 39(8), 1386-1397.

Neven, D. and T. Reardon (2004) 'The rise of Kenyan supermarkets and the evolution of their horticulture product procurement systems', Development Policy Review, 22(6), 669-699. 
Neven, D. and T. Reardon (2006) 'Kenyan supermarkets and horticultural farm sector development, In Contributed Paper Prepared for Presentation at the International Association of Agricultural Economists Conference, Gold Coast, Australia, August (pp. 12-18).

Oduol, J., Place, F., Dagmar, M., Olwande, J., Kirimi, L. and M. Mathenge (2013) 'Improving participation in agricultural commodity markets for smallholder avocado farmers in Kenya: assessing growth opportunities for women in Kandara and Marani districts', Nairobi: Tegemeo Institute of agricultural policy and development.

Ouma, S (2010) 'Global standards, local realities: private agrifood governance and the restructuring of the Kenyan horticulture industry', Economic Geography, 86(2), 197-222.

Pickles, J., Barrientos, S. W. and Knorringa, P. (2016) 'New end markets, supermarket expansion and shifting social standards', Environment and planning A, 48(7), 1284-1301.

Pietrobelli, C. and R. Rabellotti (2007) Upgrading to compete: SMEs, clusters and value chains in Latin America, Cambridge Mass: Harvard University Press.

Pietrobelli, C. and R.Rabellotti (2011) 'Global value chains meet innovation systems: are there learning opportunities for developing countries?', World Development, 39(7), 1261-1269.

Ponte, S. and J. Ewert (2009) Which way is "up" in upgrading? Trajectories of change in the value chain for South African wine', World Development, 37(10), 1637-1650.

Rao, E. J. O. and M. Qaim (2011) 'Supermarkets, farm household income, and poverty: insights from Kenya', World Development, 39(5),784-796.

Reardon, T., Henson, S. and J. Berdegué (2007) 'Proactive fast-tracking' diffusion of supermarkets in developing countries: implications for market institutions and trade', Journal of Economic Geography, 7(4), 399-431.

Riisgaard, L. (2009) 'Global value chains, labor organization and private social standards: Lessons from East African cut flower industries', World Development, 37(2), 326-340.

Schipmann, C. and M. Qaim (2010) 'Spillovers from modern supply chains to traditional markets: product innovation and adoption by smallholders', Agricultural Economics, 41(3-4), 361-371.

SNV (2012) 'The Beans Value Chain in Kenya', Netherlands, available at: http://www.snvworld.org/en/countries/kenya/publications/the-beans-value-chain-in-kenya [Accessed May 23, 2015].

Tschirley, D. L., Muendo, K. M. and M.T. Weber (2004) 'Improving Kenya's Domestic Horticultural Production and Marketing System: Current Competitiveness, Forces of Change, and Challenges for the Future', Volume II: Horticultural Marketing: Michigan State University, Department of Agricultural, Food, and Resource Economics.

Wasilwa, L. A., Njuguna, J. K., Okoko, E. N. and G.W. Watani (2006) 'Status of avocado production in Kenya', Nairobi: Kenyan Agricultural research institute.

World Bank (2015) World Bank databank, available at: http://databank.worldbank.org/data/home.aspx [Accessed January10, 2015]. 


\section{TABLES}

Table 1: Implications of opportunistic spillover interactions for suppliers

\begin{tabular}{|c|c|c|c|c|c|c|c|c|c|}
\hline $\begin{array}{c}\text { Farmer } \\
\text { category by } \\
\text { main buyer }\end{array}$ & $\begin{array}{c}\text { Overlap of } \\
\text { chains (Second } \\
\text { buyers) }\end{array}$ & $\begin{array}{c}\text { Strategic } \\
\text { diversific } \\
\text { ation }\end{array}$ & $\begin{array}{c}\text { Average } \\
\text { income } \\
\text { for } \\
\text { avocados } \\
\text { before* } \\
\text { (USD/ } \\
\text { year) }\end{array}$ & $\begin{array}{c}\text { Average } \\
\text { income } \\
\text { for } \\
\text { avocados } \\
\text { 2014-15 } \\
\text { (USD/ } \\
\text { year) }\end{array}$ & $\begin{array}{c}\text { Average } \\
\text { income } \\
\text { for } \\
\text { French } \\
\text { bean } \\
\text { before* } \\
\text { (USD/ } \\
\text { year) }\end{array}$ & $\begin{array}{c}\text { Average } \\
\text { income } \\
\text { for } \\
\text { French } \\
\text { bean } \\
\text { 2014-15 } \\
\text { (USD/ } \\
\text { year) }\end{array}$ & $\begin{array}{c}\text { Average } \\
\text { \% change } \\
\text { in income } \\
\text { (across } \\
\text { both } \\
\text { crops) }\end{array}$ & $\begin{array}{c}\% \% \text { of } \\
\text { farmers } \\
\text { reporting } \\
\text { improved } \\
\text { bargaining } \\
\text { position } \\
\text { since } \\
\text { diversificati } \\
\text { on** }\end{array}$ & $\begin{array}{c}\text { Average } \\
\text { number of } \\
\text { years since } \\
\text { diversification }\end{array}$ \\
\hline $\begin{array}{l}\text { Farmers } \\
\text { supplying } \\
\text { to export } \\
\text { markets } \\
\text { (GVCs) }\end{array}$ & $\begin{array}{c}\text { Regional } \\
\text { supermarkets } \\
\text { (RVC) }\end{array}$ & Yes & 1165 & 1561 & 1661 & 1982 & +26.6 & +45 & 3 \\
\hline $\begin{array}{l}\text { Farmers } \\
\text { supplying } \\
\text { to export } \\
\text { markets } \\
\text { (GVCs) }\end{array}$ & $\begin{array}{l}\text { Wet/wholesale } \\
\text { markets (RVC) }\end{array}$ & Yes & 1098 & 1333 & 1592 & 1788 & +16.85 & +0.5 & 5 \\
\hline $\begin{array}{l}\text { Farmers } \\
\text { supplying } \\
\text { ONLY to } \\
\text { export } \\
\text { markets } \\
\text { (GVCs) }\end{array}$ & None & No & 1162 & 1398 & 1650 & 1754 & +13.3 & +8 & $\mathrm{NA}$ \\
\hline
\end{tabular}


Table 2: Sourcing strategies of key regional supermarkets in targeted RVCs

\begin{tabular}{|c|c|c|c|c|c|}
\hline $\begin{array}{c}\text { Sourcing } \\
\text { /Supermarkets }\end{array}$ & Nakumatt & Uchumi & Naivas & Tuskys & Chandarana \\
\hline $\begin{array}{c}\text { Procurement } \\
\text { / Distribution } \\
\text { strategy }\end{array}$ & $\begin{array}{l}\text { Dedicated } \\
\text { company: } \\
\text { Centralized } \\
\text { distribution }\end{array}$ & $\begin{array}{l}\text { In store and } \\
\text { outsourced to } \\
\text { multiple } \\
\text { intermediary } \\
\text { companies }\end{array}$ & $\begin{array}{c}\text { In store and } \\
\text { outsourced to } \\
\text { multiple } \\
\text { intermediary } \\
\text { companies }\end{array}$ & $\begin{array}{l}\text { Dedicated } \\
\text { company: } \\
\text { Centralized } \\
\text { distribution }\end{array}$ & $\begin{array}{c}\text { In store and } \\
\text { outsourced to } \\
\text { multiple } \\
\text { intermediary } \\
\text { companies }\end{array}$ \\
\hline $\begin{array}{l}\text { Grading for } \\
\text { standards }\end{array}$ & $\begin{array}{l}\text { Experts from } \\
\text { dedicated } \\
\text { companies } \\
\end{array}$ & $\begin{array}{l}\text { In store and } \\
\text { outsourced } \\
\text { company }\end{array}$ & $\begin{array}{c}\text { In store and } \\
\text { outsourced } \\
\text { company }\end{array}$ & $\begin{array}{c}\text { Experts from } \\
\text { dedicated } \\
\text { companies }\end{array}$ & $\begin{array}{c}\text { In store } \\
\text { professionals }\end{array}$ \\
\hline Traceability & $\begin{array}{l}\text { Dedicated } \\
\text { company - } \\
\text { maintains } \\
\text { record } \\
\end{array}$ & $\begin{array}{c}\text { Record } \\
\text { maintenance - } \\
\text { differs per } \\
\text { store } \\
\end{array}$ & $\begin{array}{c}\text { Record } \\
\text { maintenance - } \\
\text { differs per } \\
\text { store } \\
\end{array}$ & $\begin{array}{c}\text { Dedicated } \\
\text { company - } \\
\text { maintains record }\end{array}$ & $\begin{array}{c}\text { Record } \\
\text { maintenance - } \\
\text { differs per } \\
\text { store }\end{array}$ \\
\hline $\begin{array}{l}\text { Target } \\
\text { Income } \\
\text { Group }\end{array}$ & Middle, Upper & Middle, Upper & Lower, Middle & Lower, Middle & Middle, Upper \\
\hline
\end{tabular}


Table 3: Implications of targeted interactions for suppliers

\begin{tabular}{|c|c|c|c|c|c|c|c|c|c|}
\hline $\begin{array}{c}\text { Upgrade/ } \\
\text { Downgrade } \\
\text { of supplier } \\
\text { (farmer) }\end{array}$ & $\begin{array}{c}\text { Main RVC } \\
\text { buyer }\end{array}$ & $\begin{array}{c}\text { Previous } \\
\text { buyers }\end{array}$ & $\begin{array}{c}\text { Average } \\
\text { time since } \\
\text { change in } \\
\text { chain } \\
\text { participation } \\
\text { (years) }\end{array}$ & $\begin{array}{c}\text { Average } \\
\text { income for } \\
\text { avocados } \\
\text { before ** } \\
\text { (USD/year) }\end{array}$ & $\begin{array}{c}\text { Average } \\
\text { income for } \\
\text { avocados } \\
\mathbf{2 0 1 4 - 1 5} \\
\text { (USD/year) }\end{array}$ & $\begin{array}{c}\text { Average } \\
\text { income for } \\
\text { French } \\
\text { bean } \\
\text { before** } \\
\text { (USD/year) }\end{array}$ & $\begin{array}{c}\text { Average } \\
\text { income for } \\
\text { French } \\
\text { bean } 2014- \\
15 \\
\text { (USD/year) }\end{array}$ & $\begin{array}{l}\text { Average } \% \\
\text { change in } \\
\text { income } \\
\text { (across } \\
\text { both } \\
\text { crops) }\end{array}$ & $\begin{array}{c}\% \% \text { of } \\
\text { farmers } \\
\text { reporting } \\
\text { improved } \\
\text { bargaining } \\
\text { position } \\
\text { across } \\
\text { both crops } \\
\text { since shift } \\
(\%)^{* *} \\
\end{array}$ \\
\hline $\begin{array}{l}\text { Downgraded } \\
\text { from GVCs }\end{array}$ & $\begin{array}{c}\text { Regional } \\
\text { Supermarket }\end{array}$ & $\begin{array}{c}\text { International } \\
\text { retailers } \\
(\mathrm{GVC})\end{array}$ & 5 & 1132 & 1295 & 1590 & 1785 & +13.33 & +19 \\
\hline $\begin{array}{l}\text { Downgraded } \\
\text { from GVCs }\end{array}$ & $\begin{array}{c}\text { Wholesalers } \\
\text { and wet } \\
\text { markets }\end{array}$ & $\begin{array}{c}\text { International } \\
\text { retailers } \\
(\mathrm{GVC})\end{array}$ & 4 & 1085 & 945 & 1562 & 1331 & -13.84 & -2 \\
\hline $\begin{array}{l}\text { New RVC } \\
\text { participant }\end{array}$ & $\begin{array}{c}\text { Regional } \\
\text { Supermarket }\end{array}$ & $\begin{array}{c}\text { Not } \\
\text { participating } \\
\text { in value } \\
\text { chains }\end{array}$ & 3 & 855 & 1155 & 975 & 1611 & $+50.16^{*}$ & $+10 *$ \\
\hline $\begin{array}{l}\text { New RVC } \\
\text { participant }\end{array}$ & $\begin{array}{c}\text { Wholesalers } \\
\text { and wet } \\
\text { markets }\end{array}$ & $\begin{array}{c}\text { Not } \\
\text { participating } \\
\text { in value } \\
\text { chains }\end{array}$ & 6 & 730 & 820 & 890 & 1035 & $+14.31 *$ & $+4 *$ \\
\hline
\end{tabular}

Note: * relative to previous livelihood $\quad * *$ before diversification **percentage of supplier ( farmer category) who answered yes to improved bargaining position 
Table 4: Interaction characteristics and implications for RVC suppliers

\begin{tabular}{|l|c|c|c|}
\hline Components & Attribute & $\begin{array}{c}\text { Opportunistic Spillover Interactions } \\
\text { (Opportunistic RVCs) }\end{array}$ & $\begin{array}{c}\text { Targeted Interactions } \\
\text { (Targeted RVCs) }\end{array}$ \\
\hline \multirow{4}{*}{ Characteristics } & Mode of product type & Spillover produce & Customized \\
\cline { 2 - 4 } & Mode of sourcing & GVC suppliers & Direct \\
\cline { 2 - 4 } & Mode of practice & Spillover practices & Explicit practices \\
\cline { 2 - 4 } & Traceability & Not required & $\begin{array}{c}\text { Mandatory; flexible in some } \\
\text { cases }\end{array}$ \\
\cline { 2 - 4 } & Governance instruments & No standards/ Minimum standard & $\begin{array}{c}\text { Explicit standards; } \\
\text { government regulation }\end{array}$ \\
\cline { 2 - 4 } & Participation: Level of strategic \\
Impliversification & High & NA \\
\hline \multirow{2}{*}{ Impations } & Balance of bargaining position & Suppliers- GVCs & Regional buyers \\
\cline { 2 - 4 } & Changes in income & Increase (Low-Moderate) & Increase (Moderate- High) \\
\hline
\end{tabular}




\section{FIGURES}

Figure 1: Opportunistic spillover Interactions in Opportunistic RVCs

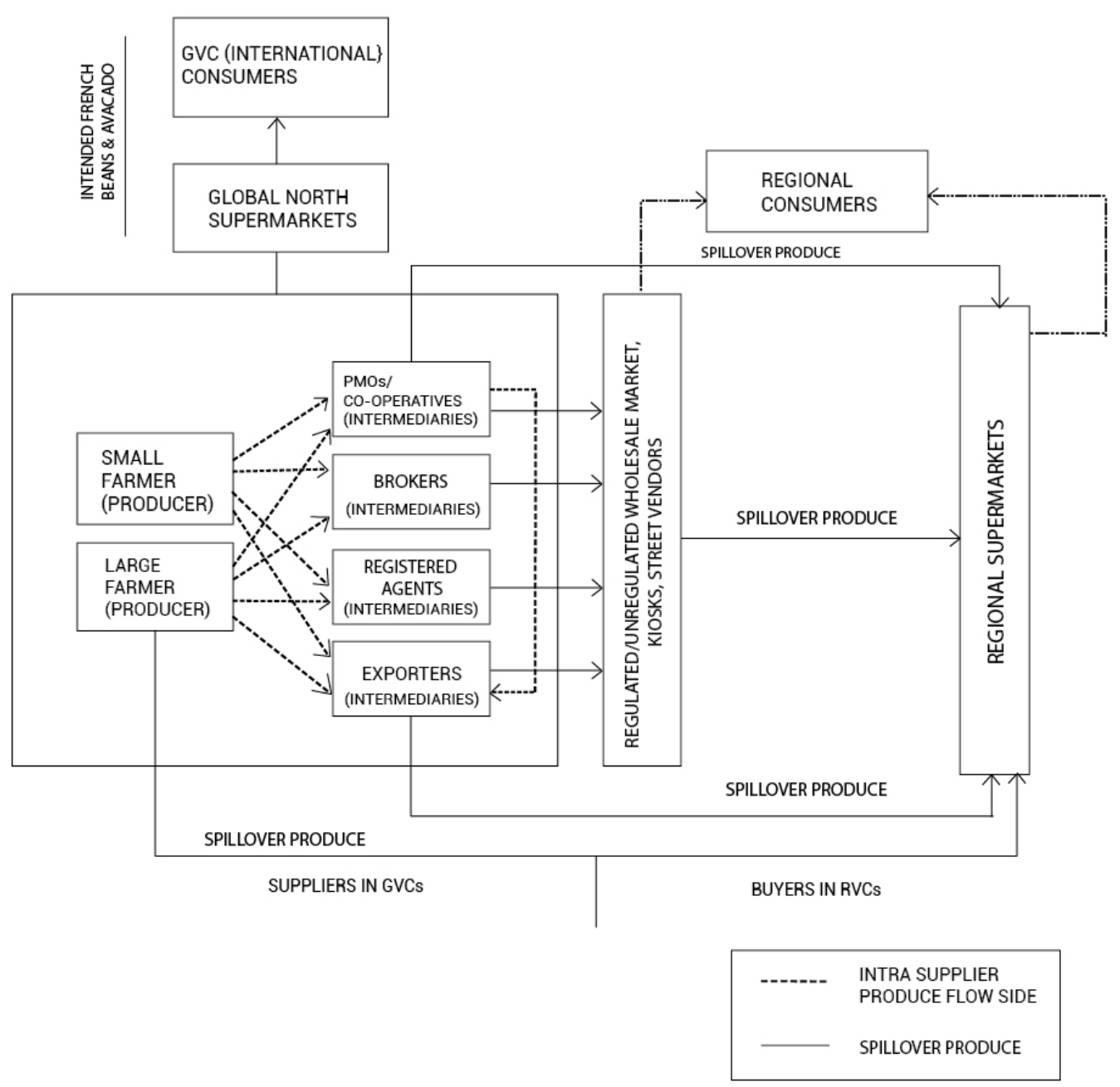

Source: Authors construction 
Figure 2: Targeted interactions in targeted RVCs

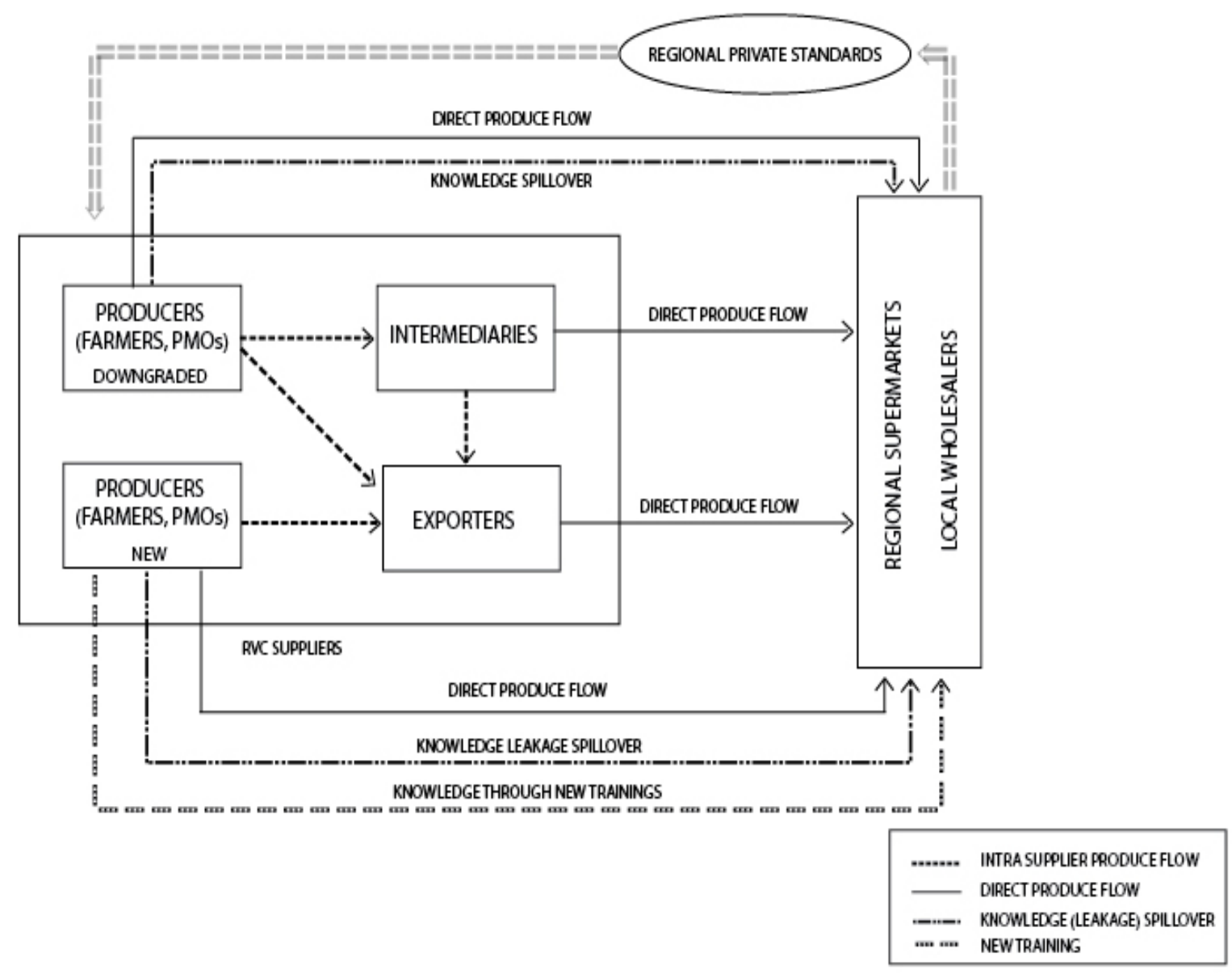

Source: Authors construction 
Figure 3: Situating hybrid interactions

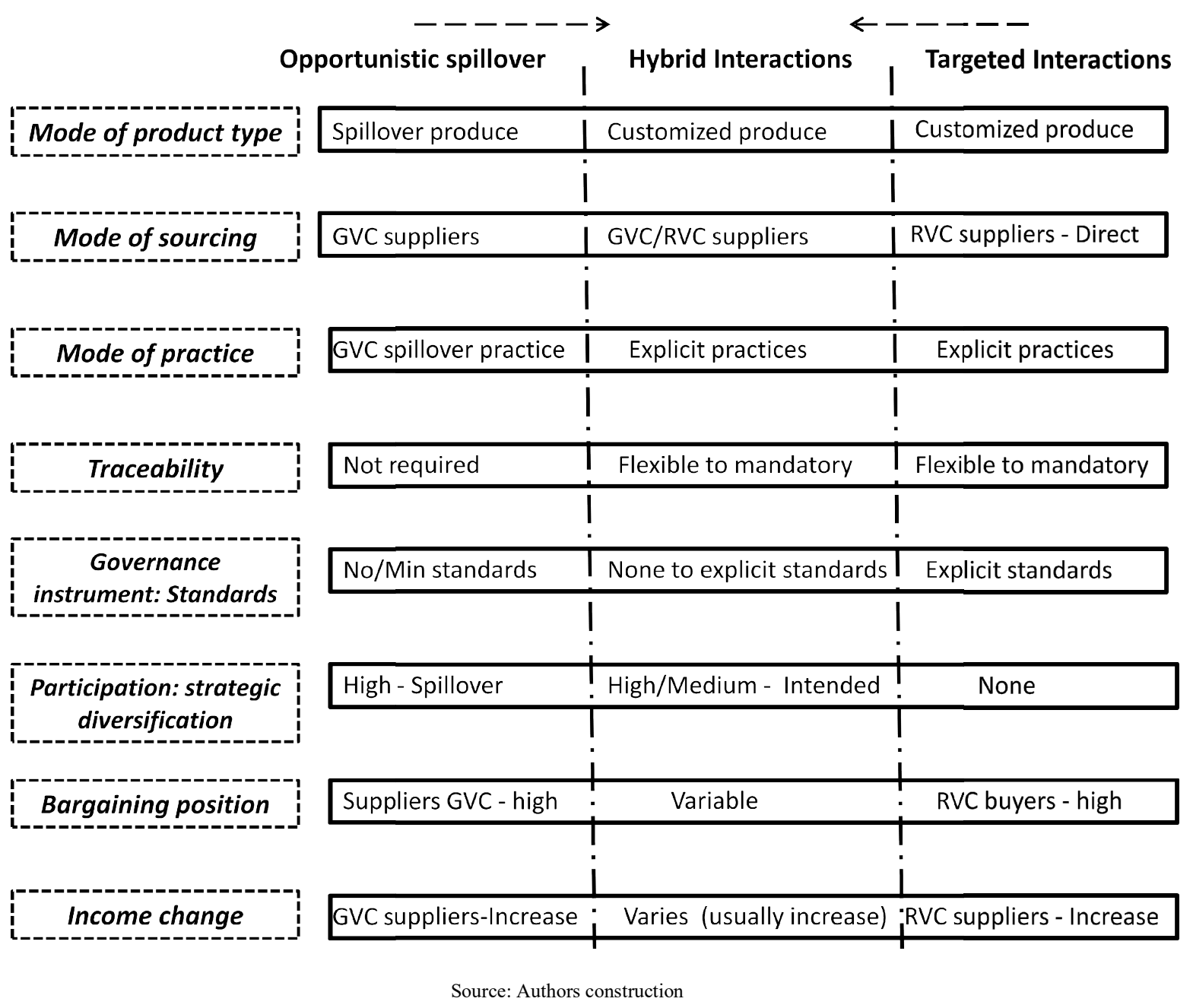

